\title{
EFEKTIVITAS PEMBERIAN HARA MIKRO MELALUI MEDIA DAN DAUN PADA TANAMAN KANGKUNG (Ipomea reptans Poir)
}

\section{Effectiveness of Micro Nutrients Through Media and Leaves on Kangkung (Ipomea reptans Poir)}

\author{
Bhaskara Anggarda Gathot Subrata ${ }^{1 *}$, dan Stefany Darsan² \\ ${ }^{1}$ Universitas Ondokuz Mayıs, Turki \\ ${ }^{2}$ Sekolah Tinggi Ilmu Pertanian Petra Baliem Wamena, Indonesia \\ *Alamat Korespondensi: bhaskaraanggarda@gmail.com
}

\begin{abstract}
ABSTRAK
Penelitian bertujuan untuk mengetahui efektivitas pemberian hara mikro melalui akar dan daun. Penelitian dilaksanakan dengan menggunakan Rancangan Acak Lengkap (RAL) faktor tunggal. Perlakuan berupa kontrol, pupuk mikro lewat media, pupuk mikro lewat daun. Masing-masing perlakuan diulang 6 kali. Media tanam berupa pasir yang sudah dimasukan ke dalam bak penanaman, setelah itu tanam benih kangkung dengan jarak 10x10 cm pada setiap bak. Lalu aplikasikan pupuk melalui media atau daun seminggu sekali. Pengamatan yang dilakukan meliputi tinggi tanaman dan kehijauan daun dengan SPAD 502 untuk tiap minggunya; aktivitas nitrate reduktase, kandungan klorofil a, klorofil b, dan klorofil total, bobot kering batang, bobot kering tajuk, bobot kering daun, bobot kering akar, luas daun (LD), serta analisis pertumbuhan tanaman, meliputi nisbah laju daun (NLD), luas daun khas (LDK), bobot daun khas (BDK). Berdasarkan penelitian yang telah dilakukan, pemberian pupuk cair melalui media maupun daun belum mampu meningkatkan pertumbuhan dan hasil tanaman kangkung. Perlakuan pada daun cenderung menunjukan hasil yang lebih tinggi dibandingkan perlakuan pada media pada semua parameter pengamatan.
\end{abstract}

Kata kunci: efektivitas, hara mikro, akar dan daun

\section{ABSTRACT}

The aim of this research is to know the effectiveness of micro nutrient giving through root and leaf. The research was conducted by using Completely Randomized Design (CRD) of single factor. Treatment of control, micro-fertilizer through the media, micro-fertilizer through the leaves. Each treatment was repeated 6 times. Planting media in the form of sand that has been inserted into the tub of planting, after that plant the seeds of kangkung with a distance of $10 \times 10 \mathrm{~cm}$ in each tub. Then apply the fertilizer through the media or leaves once a week. Observations included plant height and greenery of leaves with SPAD 502 for each week; nitrate reductase activity, chlorophyll a, chlorophyll b, and total chlorophyll, dry weight of stalk, dry weight of canopy, leaf dry weight, root dry weight, leaf area, and plant growth analysis, including leaf rate ratio, typical leaf area, typical leaf weight. Based on the research that has been done, the application of liquid fertilizer through the media and leaves has not been to increase the growth and yield of kangkung. Treatment on the leaves tend to show higher results than treatment on media at all observation parameter.

Keywords: effectiveness, micro nutrients, roots and leaves

\section{PENDAHULUAN}

Pertumbuhan dan perkembangan tanaman merupakan proses yang penting dalam kehidupan dan berlangsung secara terus menerus sepanjang daur hidup. Tumbuh merupakan suatu proses yang kompleks yang melibatkan banyak faktor yaitu faktor dalam maupun faktor luar.
Faktor dalam pertumbuhan misal asimilasi, pembentukan protoplasma baru, peningkatan dalam ukuran dan berat tumbuhan. Faktor luar yang mempengaruhi pertumbuhan tanaman yaitu kadar air dan udara dalam tanah, kelembaban udara, intensitas cahaya, tanah dan ketersedian mineral. 
Pertumbuhan suatu tanaman bergantung pada jumlah bahan makanan yang diberikan padanya. Banyaknya unsurunsur yang diambil oleh suatu tanaman memiliki pengaruh timbal balik (Dwidjoseputro, 1980). Media tanam berfungsi sebagai tempat tumbuh dan berkembangnya akar serta menahan unsur hara dan air untuk sementara waktu. Jenis dan sifat media tanam akan mempengaruhi ketersedian unsur hara dan air di daerah perakaran. Setiap media tanam akan berbeda pengaruhnya terhadap pertumbuhan dan hasil tanaman.

Kebutuhan tanaman akan unsur hara dapat diperoleh dari media tanam. Namun, biasanya unsur hara yang terdapat di dalam media tanam tidaklah lengkap dan tidak dapat memenuhi kebutuhan tanaman. Oleh karena itu, diperlukan tambahan unsur hara berupa pupuk mikro. Pemberian pupuk mikro secara rutin dan berkala serta dengan dosis yang tepat sangat menunjang petumbuhan tanaman. Sebaliknya, pemberian pupuk mikro yang berlebihan dan tidak tepat dosis akan menyebabkan pertumbuhan tanaman terganggu, bahkan dapat menyebabkan kematian (Sugih et al., 2005).Melihat permasalahan diatas maka telah dilakukan penelitian yang bertujuan untuk mengetahui efektivitas pemberian hara mikro melalui akar dan daun.

\section{METODE}

Penelitian dilakukan di rumah kaca dan laboratorium Agroteknologi Sekolah Tinggi Ilmu Pertanian Petra Baliem Wamena pada bulan April-Juni 2017. Peralatan yang dipakai adalah pipet, pengaduk, gelas ukur erlenmeyer, alat semprot, timbangan analitik, pengaris, oven, ember, timbangan, SPAD 502, dan Spectronic 21D. Sedangkan bahan yang digunakan meliputi benih kangkung, pupuk mikro, pupuk NPK, pasir.

Penelitian dilaksanakan dengan menggunakan Rancangan Acak Lengkap (RAL) faktor tunggal. Perlakuan berupa kontrol, pupuk mikro lewat media, pupuk mikro lewat daun. Masing perlakuan diulang 6 kali.Media tanam berupa pasir yang sudah dimasukan ke dalam bak penanaman, setelah itu tanam benih kangkung dengan jarak 10x10 cm pada setiap bak. Lalu aplikasikan pupuk melalui media atau daun seminggu sekali.

Pengamatan yang dilakukan meliputi tinggi tanaman dan kehijauan daun dengan SPAD 502 untuk tiap minggunya; aktivitas nitrate reduktase, kandungan klorofil a, klorofil $b$, dan klorofil total, bobot kering batang, bobot kering tajuk, bobot kering daun, bobot kering akar, luas daun (LD), serta analisis pertumbuhan tanaman, meliputi nisbah laju daun (NLD), luas daun 
khas (LDK), bobot daun khas (BDK),Data hasil pengamatan dianalisis dengan menggunakan sidik ragam. Apabila terdapat beda nyata diuji dengan Duncan's Mutiple Range Test (DMRT) 5\%.

\section{HASIL DAN PEMBAHASAN}

\section{Tinggi Tanaman}

Pemberian pupuk mikro dengan berbagai cara baik melalui daun atau media memberikan hasil tidak berbeda nyata terhadap parameter tinggi tanaman (Tabel 1). Penambahan tinggi tanaman terus meningkat pada semua perlakuan mulai dari minggu 1 hingga minggu 5 pengamatan. Hasil pengamatan menunjukan bahwa hasil tinggi tanaman tertinggi terdapat pada perlakuan kontrol pada minggu ke 2 hingga minggu ke 5, sedangkan pada minggu ke 1 hasil tertinggi ditunjukan pada perlakuan media. Perlakuan pemberian pupuk melalui media dan daun tidak berpengaruh nyata terhadap tinggi tanaman kangkung. Sejalan dengan penelitian Guievence dan Badem (2000) menyatakan bahwa efek pupuk daun tidak berbeda nyata pada parameter pertumbuhan dan hasil panen selada. Hal tersebut diperkuat oleh Nirmala (2013) menyatakan pemberian POC tidak memberika pengaruh nyata terhadap tinggi tanaman selada. Meskipun pada penelitian yang dilakukan oleh Baloch et al., (2008), pemberian pupuk daun dapat meningkatkan tinggi tanaman cabai hingga konsentrasi 8 ml/liter. Menurut Premsekhar dan Rajashree (2009) pertambahan tinggi tanaman mungkin disebabkan oleh peningkatan pembelahan dan pemanjangan sel pada pemberian dosis $\mathrm{N}$ yang meningkat. Penambahan tinggi tanaman ini diduga diperkirakan bahwa pemberian pupuk cair dapat menyebabkan terpacunya sel di ujung batang untuk segera mengadakan pembelahan dan perbesaran sel terutama di daerah meristematis.

\section{Berat Kering Tanaman}

Respon perlakuan terhadap berat kering tanaman dengan pemberian pupuk melalui media dan daun belum menunjukan hasil yang signifikan dibandingkan dengan kontrol (Tabel 2). Hal ini ditunjukan dengan hasil analisis data pengamatan yang dilakukan bahwa hampir pada semua hasil pengamatan berat kering tanaman secara keseluruhan hasil tertinggi ditunjukan pada perlakuan kontrol.

Tabel 1. Pengaruh Pemberian Pupuk Mikro Terhadap Tinggi Tanaman (cm)

\begin{tabular}{lccccc}
\hline \multirow{2}{*}{ Perlakuan } & \multicolumn{5}{c}{ Tinggi tanaman } \\
\cline { 2 - 6 } & $1 \mathrm{MST}$ & $2 \mathrm{MST}$ & $3 \mathrm{MST}$ & $4 \mathrm{MST}$ & $5 \mathrm{MST}$ \\
\hline Kontrol & $6,54 \mathrm{a}$ & $12,34 \mathrm{a}$ & $14,74 \mathrm{a}$ & $14,96 \mathrm{a}$ & $16,27 \mathrm{a}$ \\
Media & $6,68 \mathrm{a}$ & $10,31 \mathrm{a}$ & $11,86 \mathrm{a}$ & $12,77 \mathrm{a}$ & $13,99 \mathrm{a}$ \\
Daun & $6,50 \mathrm{a}$ & $12,27 \mathrm{a}$ & $14,06 \mathrm{a}$ & $14,74 \mathrm{a}$ & $15,29 \mathrm{a}$ \\
\hline
\end{tabular}

Keterangan: Angka yang diikuti huruf yang sama pada kolom yang sama menunjukkan tidak berbeda nyata pada DMRT 5\%. MST = minggu setelah tanam. 
p-ISSN: 1410-0029; e-ISSN2549-6786

Agrin Vol. 22, No. 1, April 2018

Tabel 2. Pengaruh Pemberian Pupuk Mikro Terhadap Berat Kering $(\mathrm{cm})$

\begin{tabular}{lcrrrrrrr}
\hline \multirow{2}{*}{ Perlakuan } & \multicolumn{8}{c}{ Berat Kering (gr) } \\
\cline { 2 - 9 } & \multicolumn{2}{c}{ Batang } & \multicolumn{2}{c}{ Daun } & Tajuk & Akar \\
\hline \multirow{2}{*}{ Kontrol } & $0,13 \mathrm{a}$ & $0,23 \mathrm{a}$ & $0,09 \mathrm{a}$ & $0,09 \mathrm{a}$ & $0,23 \mathrm{a}$ & $0,32 \mathrm{a}$ & $0,26 \mathrm{a}$ & $0,42 \mathrm{a}$ \\
Media & $0,08 \mathrm{~b}$ & $0,16 \mathrm{~b}$ & $0,07 \mathrm{~b}$ & $0,07 \mathrm{a}$ & $0,16 \mathrm{~b}$ & $0,24 \mathrm{~b}$ & $0,1 \mathrm{~b}$ & $0,52 \mathrm{a}$ \\
Daun & $0,05 \mathrm{c}$ & $0,14 \mathrm{~b}$ & $0,06 \mathrm{~b}$ & $0,10 \mathrm{a}$ & $0,12 \mathrm{~b}$ & $0,24 \mathrm{~b}$ & $0,07 \mathrm{~b}$ & $0,26 \mathrm{~b}$ \\
\hline
\end{tabular}

Keterangan: Angka yang diikuti huruf yang sama pada kolom yang sama menunjukkan tidak berbeda nyata pada DMRT 5\%. MST = minggu setelah tanam.

Unsur hara nitrogen dan unsur hara mikro berperan sebagai penyusun klorofil sehingga meningkatkan aktivitas fotosintesis tersebut akan menghasilkan fotosintat yang mengakibatkan perkembangan pada jaringan meristematis daun. Pemberian pupuk cair pada tanaman kangkung ini diperkirakan akan mempercepat sintesis asam amino dan protein sehingga mempercepat pertumbuhan tanaman. Hal ini sesuai dengan pendapat Rao (1994) dan Poerwowidodo (1992) yang mengatakan bahwa pupuk cair mengandung unsur kalium yang berperan penting dalam setiap proses metabolisme tanaman, yaitu dalam sintesis asam amino dan protein dari ion-ion ammonium serta berperan dalam memelihara tekanan turgor dengan baik sehingga memungkinkan lancarnya prosesproses metabolisme dan menjamin kesinambungan pemanjangan sel.

Pemberian pupuk cair baik pada media maupun daun tidak menunjukan hasil yang signifikan dibandingkan dengan kontrol. Hal ini disebabkan oleh kondisi lingkungan yang terlalu panas yang membuat pupuk yang diberikan akan menguap pada saat proses pengeringan. Badillo et al. (1977) menambahkan waktu aplikasi yang tidak tepat, rusaknya stomata dan membran berpengaruh pada ion $\mathrm{N}$ yang dapat diserap tanaman. Selain karena faktor fisiologi dan hama, diduga faktor lingkungan seperti suhu dan intensitas cahaya yang tinggi dan kekeringan pada awal tanam membuat tanaman stress.

\section{Kehijauan Daun, Klorofil dan ANR}

Klorofil meter (SPAD) merupakan alat yang dapat digunakan untuk memonitor warna daun dan jumlah klorofil. Klorofil meter menggunakan spektrum warna yang dipantulkan oleh daun (Balasubramanian et al., 1999).

Nilai SPAD berkorelasi tinggi dengan kandungan ekstak klorofil telah dilaporkan untuk beberapa spesies tanaman (Uddling et al., 2007). Sejalan dengan pendapat Sulistyaningsih dkk., (2005), salah satu pendekatan untuk mengetahui jumlah klorofil daun adalah dengan mengukur tingkat kehijauan. Daun yang lebih hijau diduga memiliki kandungan klorofil yang tinggi. Pengukuran warna daun dapat 
menggunakan klorofil meter dan leaf colour

chart. Anand dan Byju (2008) menambahkan SPAD dapat digunakan untuk memperkirakan kandungan klorofil dan sebagai indikator $\mathrm{N}$ pada daun. Pada penelitian Judkins dan Wander (1950) warna daun memiliki korelasi positif terhadap jumlah $\mathrm{N}$ pada daun apel, peach dan anggur.

Apilkasi pupuk cair pada media atau kandungan klorofil dan ANR dibandingkan dengan perlakuan kontrol (Tabel 3). Hal ini berbanding lurus dengan hasil yang ditunjukan pada kehijauan daun yang juga belum signifikan pada aplikasi pupuk cair melalui media dan daun (Tabel 4). Penyiraman yang dilakukan setelah aplikasi pupuk cair diduga mengakibatkan proses pencucian atau leaching pupuk pada permukaan daun dan media.

daun belum mampu meningkatkan

Tabel 3. Pengaruh pemberian pupuk mikro terhadap klorofil a, klorofil $b$, kloforil total dan ANR

\begin{tabular}{lrrrrrrrr}
\hline \multirow{2}{*}{ Perlakuan } & \multicolumn{2}{c}{ Klorofil a } & \multicolumn{2}{c}{ Klorofil b } & \multicolumn{2}{c}{ Klorofil Total } & \multicolumn{2}{c}{ ANR } \\
\cline { 2 - 9 } & 3 MST & 6 MST & 3 MST & 6 MST & 3 MST & 6 MST & 3 MST & 6 MST \\
\hline \multirow{2}{*}{ Kontrol } & $15,44 \mathrm{a}$ & $5,68 \mathrm{~b}$ & $0,19 \mathrm{a}$ & $0,074 \mathrm{~b}$ & $0,46 \mathrm{a}$ & $0,17 \mathrm{~b}$ & $1153,16 \mathrm{a}$ & $704,22 \mathrm{a}$ \\
Daun & $9,32 \mathrm{c}$ & $4,63 \mathrm{c}$ & $0,11 \mathrm{c}$ & $0,061 \mathrm{c}$ & $0,28 \mathrm{~b}$ & $0,14 \mathrm{c}$ & $783,45 \mathrm{~b}$ & $686,61 \mathrm{c}$ \\
Media & $13,40 \mathrm{~b}$ & $5,92 \mathrm{a}$ & $0,16 \mathrm{~b}$ & $0,081 \mathrm{a}$ & $0,41 \mathrm{c}$ & $0,18 \mathrm{a}$ & $757,04 \mathrm{c}$ & $563,38 \mathrm{~b}$ \\
\hline
\end{tabular}

Keterangan : Angka yang diikuti huruf yang sama pada kolom yang sama menunjukkan tidak berbeda nyata pada DMRT 5\%. MST = minggu setelah tanam; ANR = aktivitas nitrat reduktase.

Tabel 4. Pengaruh pemberian pupuk mikro terhadap kehijauan daun

\begin{tabular}{lccccc}
\hline \multirow{2}{*}{ Perlakuan } & \multicolumn{5}{c}{ Kehijaun daun } \\
\cline { 2 - 6 } & $1 \mathrm{MST}$ & $2 \mathrm{MST}$ & $3 \mathrm{MST}$ & $4 \mathrm{MST}$ & $5 \mathrm{MST}$ \\
\hline Kontrol & $2,27 \mathrm{a}$ & $2,83 \mathrm{a}$ & $2,81 \mathrm{a}$ & $3,08 \mathrm{a}$ & $3,33 \mathrm{a}$ \\
Media & $2,72 \mathrm{a}$ & $2,88 \mathrm{a}$ & $2,72 \mathrm{a}$ & $2,69 \mathrm{a}$ & $2,70 \mathrm{~b}$ \\
Daun & $2,69 \mathrm{a}$ & $3,02 \mathrm{a}$ & $2,75 \mathrm{a}$ & $2,69 \mathrm{a}$ & $2,87 \mathrm{~b}$ \\
\hline
\end{tabular}

Keterangan : Angka yang diikuti huruf yang sama pada kolom yang sama menunjukkan tidak berbeda nyata pada DMRT 5\%. MST = minggu setelah tanam.

Tabel 5. Pengaruh pemberian pupuk mikro terhadap LD, NLD, LDK, dan BDK

\begin{tabular}{lcccccccc}
\hline \multirow{2}{*}{ Perlakuan } & \multicolumn{2}{c}{ LD } & \multicolumn{2}{c}{ NLD } & \multicolumn{2}{c}{ LDK } & \multicolumn{2}{c}{ BDK } \\
\cline { 2 - 9 } & $3 \mathrm{MST}$ & $6 \mathrm{MST}$ & $3 \mathrm{MST}$ & $6 \mathrm{MST}$ & $3 \mathrm{MST}$ & $6 \mathrm{MST}$ & $3 \mathrm{MST}$ & $6 \mathrm{MST}$ \\
\hline \multirow{2}{*}{ Kontrol } & $47,35 \mathrm{a}$ & $42,45 \mathrm{a}$ & $96,01 \mathrm{~b}$ & $57,38 \mathrm{a}$ & $39,79 \mathrm{a}$ & $44,64 \mathrm{a}$ & $0,028 \mathrm{~b}$ & $0,025 \mathrm{a}$ \\
Daun & $44,90 \mathrm{a}$ & $37,90 \mathrm{a}$ & $173,01 \mathrm{a}$ & $54,32 \mathrm{a}$ & $55,24 \mathrm{a}$ & $42,41 \mathrm{a}$ & $0,019 \mathrm{~b}$ & $0,025 \mathrm{a}$ \\
Media & $30,67 \mathrm{~b}$ & $25,65 \mathrm{~b}$ & $159,29 \mathrm{a}$ & $54,28 \mathrm{~b}$ & $26,91 \mathrm{~b}$ & $37,32 \mathrm{a}$ & $0,042 \mathrm{a}$ & $0,026 \mathrm{a}$ \\
\hline
\end{tabular}

Keterangan : Angka yang diikuti huruf yang sama pada kolom yang sama menunjukkan tidak berbeda nyata pada DMRT 5\%. MST = Minggu Setelah Tanam; LD = Luas Daun; $\mathrm{NLD}=$ Nisbah Luas Daun; LDK = Luas Daun Khas; BDK = Bobot Daun Khas. 


\section{Analisis Pertumbuhan Tanaman}

Aplikasi pupuk cair pada media atau daun belum mampu meningkatkan luas daun, nisbah luas daun, luas daun khas, dan bobot daun khas dibandingkan dengan perlakuan control (Tabel 5). Namun demikian, pada aplikasi pada daun nilai luas daun lebih tinggi yaitu 44,9 dibandingkan dengan aplikasi pada media yaitu 30,67. Hal ini disebabkan penyerapan pupuk cair lebih efektif melalui daun dibandingkan memalui media tanam. Hasil ini sesuai dengan pendapat Ratna (2002), bahwa pemberian pupuk organik cair maupun padat dapat memacu pertambahan luas daun. Meningkatnya luas daun berarti kemampuan daun untuk menerima dan menyerap cahaya matahari akan lebih tinggi sehingga fotosintat dan energi yang dihasilkan lebih tinggi pula.

\section{KESIMPULAN}

Berdasarkan penelitian yang telah dilakukan, pemberian pupuk cair melalui media maupun daun belum mampu meningkatkan pertumbuhan dan hasil tanaman kangkung. Perlakuan pada daun cenderung menunjukan hasil yang lebih tinggi dibandingkan perlakuan pada media pada semua parameter pengamatan.

\section{DAFTAR PUSTAKA}

Anand, M. H., and G. Byju. 2008. Chlorophyll meter and leaf colour chart to estimate chlorophyll content, leaf colour, and yield of cassava. Photosynthetica, 46(4): 511-516.

Badillo, F., J.R. Abrams, and R. Pietri. 1977. Effect of foliar applied fertilizers on pigeonpeas (Cajanus cajan). Journal of Agriculture of the University of Puerto Rico, 61: 217 220.

Balasubramanian, V., A.C. Morales, , R.T. Cruz, and S. Abdulrachman, 1999. On-farm adaptation of knowledgeintensive nitrogen management technologies for rice systems. Resource management in rice systems Nutrients, 79 - 93.

Baloch, Q.B., Q.I. Chachar, and M.N. Tareen. 2008. Effect of foliar application of macro and micro nutrients on production of green chilies (Capsicum annuum L.). Journal of Agricultural Technology, 4(2): $177-184$.

Dwidjoseputro. 1980. Pengantar fisiologi tumbuhan. Gramedia, Jakarta.

Guievence, I. and H. Badem. 2000. Effect of foliar application of different sources and levels of nitrogen on growth and yield of tomato. Indian $J$. Agric. Sci., 72(2): $104-105$.

Judkins, W.P. and I.W. Wander. 1950. Correlation between leaf color, leaf nitrogen content, and growth of apple, peach, and grape plants. Plant physiology, 25(1): 78 - 85 .

Nirmala, R., 2013. Pengaruh konsentrasi pupuk organik cair kosarine terhadap pertumbuhan dan hasil tanaman selada (Lactuca sativa L). Agrin, 17(2): 113 - 121.

Poerwowidodo, 1992. Telaah Kesuburan Tanah. Penerbit Angkasa, Bandung.

Premsekhar, M. and V. Rajashree. 2009. Influence of organic manures on growth, yield and quality of okra. American Eurasian Journal of Sustainable Agriculture, 3(1): 6-8. 
Rao, S. 1994. Mikroorganisme dan pertumbuhan tanaman. Univ. Indonesia. Jakarta

Ratna, D.I. 2002. Pengaruh kombinasi konsentrasi pupuk hayati dengan pupuk organikcair terhadap kualitas dan kuantitas hasil tanaman teh (Camellia sinensis L.) klon gambung 4. Ilmu Pertanian, 10(2): $17-25$

Sugih, J., C. Hyunseok, M. Morley, and W. Walter. 2005. An empirical approach to modeling inter-as traffic matrices. IMC.
Sulistyaningsih, E., B. Kurniasih, and E. Kurniasih. 2005. Pertumbuhan dan hasil caisin pada berbagai warna sungkup plastik growth and yield of mustard greens in many convex plastic covers. Ilmu Pertanian, 12(1): $65-76$.

Uddling, J., J. Gelang-Alfredsson, K. Piikki, and H. Pleijel. 2007. Evaluating the relationship between leaf chlorophyll concentration and SPAD-502 chlorophyll meter readings. Photosynthesis Research, 91(1): $37-46$. 